\title{
Study on the Improvement of Execution Ability of Ideological and Political Education for College Students
}

\author{
--Based on the Connection Mechanism of Ideological and Political Theory Course Teacher \\ and Counselor
}

\author{
Wenying Lu \\ Xi'an Peihua University, Xi'an 710125, China
}

Keywords: Connection Mechanism; Ideological and Political Education; Execution Ability

\begin{abstract}
The popularization of Internet information technology makes students exposed to mixed multiple information, thus affecting the effectiveness of ideological and political education, together with the lack of connection mechanism of the ideological and political education in college, which weakens the execution ability of ideological and political education in college. For these problems, we establish connection between counselor and ideological and political theory course teacher--two main force of ideological and political education in college, with management system in college as constraints, with the help of Internet information technology platform to combine the inside and outside, online and offline ideological and political education courses, finally realize seamless connection and full participation of all staff in the whole process, and promote to improve execution ability of ideological and political education in college effectively. The innovation of this paper is to combine the management of counselor and the teaching of ideological and political theory course teacher to produce "one plus one is greater than two" effects.
\end{abstract}

\section{Introduction}

At present, our country has entered a stage of building a moderately prosperous society in an all-round way. Several years later, college students will step into all walks of life and become the mainstay of our country facing the modernization, the world and the future. Therefore, the Communist Party of China and the country attach great importance to ideological and political education for college students. In December 2016, General Secretary Xi Jinping pointed out in his speech at the National Ideological and Political Work Conference of Colleges and Universities that "we should stick to take the high moral values establishment and people cultivation as central part, carry out the ideological and political work throughout the entire process of education and teaching so as to educate people in the whole process and in an all-round way and make efforts to open up new prospects for the development of higher education cause in our country. " This has put forward new requirements for the ideological and political education in our country in the new era and pointed out a new direction. In carrying out the ideological and political education, we must integrate the development of times, introduce information technology into the ideological and political education system, improve the execution ability of ideological and political education in a creative way, and achieve the people-oriented educational goal with the development of students as the center.

\section{Factors influencing the execution ability of ideological and political education in college}

2.1 The impact of the popularization of Internet information technology on ideological and political education

\subsubsection{Influences of diversified Internet information content on ideological and political education in college}

The universal application of Internet information technology makes it easier for people to learn 
knowledge, share resources, exchange experience and ideas, express opinions and comments, and digital natives of the Internet -- students of the post-1995 generation are more exposed to various contents and opinions of ideological and political education, positive or negative, in line with the mainstream of the socialist core values, or contrary to the mainstream view. In addition, the Internet monitoring technology in current stage is incomplete, and inexperienced college students with inadequate social experiences and strong political discriminability are unable to identify, which may lead them to have deviations on understanding matters, thus affecting the formation of their values and value of right and wrong. With the rapid development of the Internet, the impact of multiple and diversified ideology and values increases the difficulty of the current ideological and political education work of students. Although ideological and political theory course teacher and counselor are also connected in ideological and political education for college students and the application of Internet information technology continues to spread, scattered behaviors of individuals are the majority and not timely.

\subsubsection{Students' superficial understanding of ideological and political education}

The progress of Internet information technology diversifies the content of ideological and political education, at the same time, corresponding revolution is happening in the way of conveying. However, educators find that whether in the course of the traditional daily instructions or the "Internet + "ideological and political education with the help of Internet information platform, a large number of students are reluctant to take the initiative to participate in the course, and seldom take the initiative to ask questions even if they do not understand. As for the reason, students do not agree with the significance of ideological and political education for their self-growth, and therefore do not want to devote time and efforts to learn and explore these knowledge and theory, and it is even more impossible to ask them to combine theory with practices. However, from the point of the self-development of individual-student, the actual need of society-student employment or the need of nation-international ideological struggle, it is necessary for students to study hard the content of ideological and political education, start from the daily learning practices and contact with reality, and gradually form a scientific world view, view of life and values. However, at present, many students fail to truly understand and grasp various influences and needs of the ideological and political education on their own development. Therefore, in the new era, the understanding of college students themselves about ideological and political education has become another important factor that affects the execution ability of ideological and political education.

\subsection{Lack of connection idea and corresponding orientation of ideological and political education work in college}

Through the more than ten colleges and universities of different levels that we have actually visited, we find that generally there is a lack of connection and ideological orientation among the ideological and political theory course teacher and counselor-the main part of the ideological and political education in college. Reasons concluded of this state is the lack of constraints of rigid rules and regulations, also the lack of flexible recognition of each other and the concept of cooperative education.

First, there is little collaboration and connection mechanism between the parties involved in ideological and political education in the actual existing rules and regulations in colleges and universities, and few measures stipulating that ideological and political theory course teacher and counselor should work together to enhance students' execution ability and effects of their ideological and political education, if any, content is vague and lacks maneuverability. In addition, at present, management of most colleges and universities is fragmented severely, ideological and political theory course teacher and counselor belong to different departments, and have clear duties, which has led to the lack of communication and coordination between the two main parts of ideological and political education that should complement each others' advantages and closely cooperate with each other, and the lack of information sharing, high level of collaboration and cooperation, thus weakening the execution ability of ideological and political education.

Second, the mutual recognition of the work of ideological and political theory course teacher and 
counselor is not ideal either. Part of ideological and political theory course teachers, in the face of phenomenon that there is a large number of students asking for leave before and after holidays, and class cadres often skip class to assist counselor to deal with class administrative affairs, communicate less with counselors, and subjectively think the quality of counselor is poor. At the same time, some counselors also subjectively think that ideological and political theory courses are of little use to students and ideological and political theory course teachers do not play a big role in the development of students. The lack of agreement and support for subjective assumptions about the work of each other is to a large extent the result of inadequate communication and poor communication.

Third, the majority of ideological and political theory course teachers in colleges (hereinafter referred to as the ideological and political teacher) and counselors, are all lack of the ideology and understanding of serving the ideological and political education jointly for students in the ideological level. The vast majority start from their own job responsibilities and tasks, ideological and political teachers require students to cooperatively complete the teaching program, and counselors require students to manage their daily affairs. As for the effectiveness of ideological and political education and the growth and development of students, ideological and political teachers and counselors do not pay much attention. Therefore, in the thinking of most ideological and political teachers and counselors, there are many ideological consciousness of "one section for one railway police", and few consciousness and idea of serving the same main part and taking the initiative to connect each other for collaborative work, let alone the measures of connection mechanism and implementation to practices in the practice of ideological and political education.

\section{Strategies of improving the execution ability of ideological and political education in college under the guidance of connection mechanism}

\subsection{Colleges and universities guide both sides to cooperatively complete ideological and political education for students in connection mechanism from the dimension of system.}

System guides the improvement of the execution of ideological and political education. First of all, it is necessary to formulate the operable content of the system that improves and develops continuously in practices. For instance, counselors and ideological and political teachers of the same school or faculty should hold joint meetings on a regular basis to focus on common problems in the ideological and political education, counselors and ideological and political teachers should often communicate with each other and focus on specific problems, and minutes and notes shall be recorded for each meeting as the performance appraisal content for the two parties, and indicators shall be quantified so that they could complement the each other' advantages and give play to their respective professional knowledge and skill. The constraints of link system encourage counselors to share their work experience to the ideological and political teachers to provide a good foundation and reference for ideological and political teachers to communicate and exchange with students and get more closed to students; Meanwhile, it guides the ideological and political teachers to give full play to the advantages of theoretical research and academic profession to provide counselors with better opportunities to learn and improve. Only in this way, can the quality and ability of the two parties be comprehensively improved in order to achieve the best educational effectiveness.

\subsection{The cooperation of their respective responsibilities under the connection mechanism realizes seamless connection of the ideological and political education for students in the whole process.}

General Secretary Xi Jinping made clear at the National Ideological and Political Work Conference that the ideological and political work should be carried out throughout the entire process of education. In order to improve the execution ability of ideological and political education within colleges and universities, ideological and political theory course teachers and counselors, as the backbone in ideological and political education for college students, should play their respective roles and work cooperatively to cultivate students, which is an inevitable choice, and seamless 
connection of the ideological and political education for students would be realized from the level of space-time and cognition.

First of all, to combine inside and outside classroom and improve students' identity of ideological and political theory and ability to solve problems. Ideological and political theory course teachers, on the one hand, are engaged in knowledge production and dissemination, on the other hand, they also have a political role to serve for the national ideology, and the role "to guide the diversified social value orientation that may exist among students with a unified mainstream ideology ". Therefore, the work of ideological and political theory course teachers is strongly political, ideological and targeted. Whereas, counselors influence students subtly and more intuitively in the daily life, and they are "political thought leader", "learning mentor", "life guide", and "affairs manager". Therefore, in the space-time connection of students' ideological and political education process, ideological and political theory course teachers need to combine the students' practices, complete the theoretical teaching, clarify the theory and lead students to really understand it theoretically; When in the concrete life practice, the guidance and supervision of counselors is needed. The close cooperation of counselors and ideological and political theory course teachers in time and space would reduce the disjointed phenomenon of ideological and political education in theory and practice.

Second, to combine online and offline classroom and instantly understand ideological and political information and news. With the profound changes in the external environment such as economic globalization, information networking and cultural diversity, value orientation, subject consciousness and individual needs of college students change dramatically. The situation faced by ideological and political education of college students is more complicated, and the challenges they face is more severe, and it is impossible for individual ideological and political theory course teacher or counselor to meet the personalized needs of college students. Educators need to abandon the traditional thinking, find new focus, promote the integration and correlation of various systems, explore ways to maximize the integration of various systems, and effectively enhance the input-output ratio of ideological and political education. This can start from one of the characteristics of college students - the digital natives of the Internet to make full use of Internet information technology. The essence of "Internet + " is to achieve changes in innovation through resources sharing, opening up and collaboration to the pursuit of maximum efficiency. Therefore, in the ideological and political education, colleges and universities establish a corresponding exchange platform. On the one hand, ideological and political theory course teachers, counselors and class committee members all join the class group (WeChat, qq), and members of the group share all kinds of information about the class, especially ideological and political education information. On the other hand, with the help of course learning platform, counselors as teaching assistant join the network ideological and political course platform. Within the platform, both ideological and political teachers and counselors can obtain the situation on study of students through the platform data so as to enhance the execution ability of ideological and political education more specifically and effectively.

\subsection{To respect the law of development of things and law of cognition, and to fully participate in the ideological and political education for students}

In the process of ideological and political education, "the accumulation of knowledge to the formation of methodology and the sublimation of values is a relatively long period. And it is even harder to explain the reality with these theories". Therefore, on the one hand, we must comply with Marx's law of cognition to complete the learning process of the content of ideological and political education so as to enhance the execution ability of ideological and political education. From the acceleration of students to understand thoroughly the Party's theories, guidelines and policies, to the sublimation of perceptual knowledge to conceptual knowledge, and to the gradual internalization to their own ideas; and then we help them put conceptual knowledge into practice. Because individuals engaged in ideological and political education have different ways of thinking, the communication and exchanges under the guidance of the link mechanism will be more conducive to 
conducting the guidance of ideological and political education for students. For instance, in the face of network hot events, counselors and ideological and political teachers should communicate at the first time, learn from each other, seek common ground while reserving differences to reach an agreement, so that ideological and political teachers in the classroom or counselors in daily life with students, both can guide and correct students' ideological understanding more scientifically and rationally from different paths of the same general direction.

On the other hand, ideological and political teachers and counselors in the same class as main force, lead other course teachers to contact and communicate with each other on a regular basis so as to understand various affairs and situations of class and students, make full use of the resources around them, continuously optimize the thinking and ideas of teaching staff about the various conditions of students and then communicate with each other. In this way, it is not only the two parts that conduct ideological and political education for students, just like that the two suns combine energy further after absorbing enough energy in their respective fields. Therefore, the situation of more people and more wisdom would be realized in the ideological and political education of students, combined the reality of colleges and universities in the whole process and strategies of efficient ideological and political education execution would be put forward.

\section{Conclusion}

In analyzing the questions of diversified contents, low recognition of students and lack of connection between the main body of education existing in current ideological and political education, under the premise of the link, such three strategies as system constraints of colleges, strengthened connection between inside, outside classroom and online, offline classroom, and full participation for the two main bodies of ideological and political education are put forward to enhance the execution ability of ideological and political education. However, just as the law of the unity of opposites in the Marxist philosophy principle, ideological and political teachers and counselors have their own responsibilities in the ideological and political education, and at the same time they all serve the ideological and political education for students. Therefore, in the connection mechanism, we cannot neglect the difference of their duties but only emphasize the service of the same object; And we should not neglect to serve the same object, but only emphasize the differences in their respective duties. We should take a good balance between opposites and unification, or one-sided exaggeration and consequences of 'beyond is as wrong as falling short' may occur.

\section{Acknowledgements}

This paper is the phased achievements of Shaanxi Province education science planning research project, No. SGH17H460; This is also research achievements of ideological and political education research project of Xi'an Peihua University, No. PHSZ20161113.

\section{References}

[1] Li Xiufang, Wang Xin. Study on Cooperative Mechanism of Education of Ideological and Political Theory Course Teacher and Counselor [J]. Study of Ideological and Political Course, 2016, (4):46-50.

[2] Li Hui. How to Enhance the Effect of Ideological and Political Education in the New Media Environment [J]. Journal of College Advisor, 2016,8(1):31-33,37.

[3] Chen Dong. On Construction of Connection Mechanism between Political and Ideological Teachers and Political Counselors in Universities [J]. Journal of Neijiang Normal University, 2016,31(5):111-114.

[4] Xu Liuqing. Study on Communication Mechanism between Political and Ideological Teachers and Counselors [J]. Journal of Suzhou Education Institute, 2016,19(1): 109-110. 